\title{
MORFOMETRIJA IN GOSTOTA VRTAČ NA IZBRANIH POBOČJIH SLOVENSKEGA
}

\section{KRASA}

Izvirni znanstveni članek

COBISS 1.01

DOI: $10.4312 /$ dela.56.89-108

\section{Izvleček}

Vrtače so najbolj tipična površinska oblika krasa zmernih geografskih širin. Na podlagi obdelave digitalnega modela višin z orodji GIS smo proučili gostoto vrtač in njihove morfometrične lastnosti glede na naklon pobočij. Proučena so bila tri območja s primerljivimi reliefnimi, geološkimi, podnebnimi in hidrološkimi značilnostmi na Hrušici, Snežniku ter Slavniškem pogorju. Ugotovili smo, da se gostota in večina izbranih morfometričnih lastnosti spreminjajo sorazmerno z naklonom površja.

Ključne besede: geomorfologija, GIS, daljinsko zaznavanje, digitalni model višin, naklon, Slovenija

${ }^{\star}$ Kirschentalgasse 16e, AT-6020 Innsbruck, Avstrija

e-pošta: novljan.ziva@gmail.com 


\title{
MORPHOMETRY AND DENSITY OF DOLINES ON SLOPES OF SLOVENIAN KARST
}

\begin{abstract}
Dolines are the most typical surface form of mid-latitude karst. Analyses of digital elevation model with GIS make it possible to study the doline density and their morphometric characteristics as a function of the slope on which they are located. Three areas with comparable relief, geological, climatic and hydrological conditions on the Hrušica, Snežnik and Slavnik hills were studied. The results show proportionality of density and most of the selected morphometric parameters with slope inclination.
\end{abstract}

Keywords: geomorphology, GIS, remote sensing, digital elevation model, slope inclination, Slovenia

\section{UVOD}

Vrtače so najbolj tipična in pogosta površinska kraška reliefna oblika zmernih geografskih širin (Ford, Williams, 2007; Sweeting, 1972; Waltham, Fookes, 2003). So kraške kotanje $z$ bolj ali manj pravilnimi krožnimi obodi in konkavnimi profili pobočij ter različnih dimenzij, premer njihovih obodov pa je večji od njihovih globin (Gams, 2004; Sauro, 2012). Vrtače največjo gostoto dosegajo na kompaktnih apnencih (Gams, 2000; Frelih, 2014). Nižje gostote vrtač so bile izmerjene na paleogenskih apnencih, najvišje pa na krednih apnencih (Mihevc, 2001; Radinja, 1969). Vrtače so oblikovane na površju z nakloni do $24^{\circ}$ (Frelih, 2014) oziroma 30-33 (Gams, 2000; Kranjc, 1981), $90 \%$ pa jih je na površju z nakloni do $20^{\circ}$ (Mihevc, Mihevc, 2021). Lega vrtač na pobočju povzroča tudi asimetrijo, saj so podaljšane v smeri naklona. Višje ležeča pobočja vrtač so položnejša, saj zbirajo več vode in je raztapljanje tako intenzivnejše kot na nižje ležečih pobočjih, ki so strmejša (Ford, Williams, 2007; Jennings, 1971). Praviloma naj bi bile starejše vrtače globlje (Habič, 1978).

Kljub številnim raziskavam vrtač pa njihova gostota in morfometrične lastnosti $\mathrm{v}$ odvisnosti od različnih vrednosti naklona pobočja še niso bile sistematično proučene. Na podlagi reliefnih, geoloških, hidroloških in podnebnih značilnosti smo izbrali tri območja proučevanja na slovenskem krasu. Vrtače smo na izbranih območjih identificirali z uporabo avtomatiziranega postopka daljinskega zaznavanja kraških kotanj na podlagi digitalnega modela višin (Digitalni model ..., 2017; Grlj, 2014), vizualne interpretacije prostorskih podatkov ter terenskega pregleda. Iz pridobljenih podatkov smo nato izračunali gostoto in morfometrične lastnosti vrtač, ki smo jih v nadaljevanju med sabo primerjali glede na naklon površja. 


\section{TEORETSKA IZHODIŠČA}

Vrtače so majhne do srednje velike kraške kotanje in so tipične ter najbolj pogoste reliefne oblike krasa zmernih geografskih širin (Sweeting, 1972). Nastajajo na karbonatnih kamninah ali na evaporitih, lahko pa tudi na silikatnih kamninah, kot je kvarcit (Waltham, Fookes, 2003). Njihov nastanek je posledica različnih procesov - raztapljanja, udorov, sufozije in pogrezanja, najpogosteje pa gre za kombinacijo teh procesov v odvisnosti od različnih litoloških in strukturnih dejavnikov v okolju (Ford, Williams, 2007; Mihevc, 2010; Sauro, 2012). Obodi vrtač so bolj ali manj okrogle oblike, profili pa so konkavni (Ford, Williams, 2007; Gams, 2004; Sauro, 2012). Vrtače v globino merijo od nekaj decimetrov do nekaj deset metrov, izjemoma tudi več kot sto metrov, njihovi premeri pa so v razponu od nekaj do tisoč metrov (Ford, Williams, 2007; Sweeting, 1972). Za vrtače je značilno, da so premeri oboda večji od globin (Gams, 2004). Pobočja vrtač so lahko položna, le blago nagnjena, ali pa strma, že skoraj stenasta, ter skalnata ali poraščena (Ford, Williams, 2007; Sauro, 2012). Vrtače, ki so oblikovane na pobočjih, so plitvejše pod nižje ležečim delom oboda. Višje ležeči deli njihovih pobočij so bolj uravnani, saj naj bi zbirali več vode in je raztapljanje tako bolj intenzivno kot na nižje ležečih pobočjih, ki so bolj strma (Ford, Williams, 2007; Jennings, 1971). Praviloma naj bi bile starejše vrtače globlje (Habič, 1978).

$\mathrm{Na}$ oblikovanost in gostoto vrtač vplivajo različni dejavniki v prostoru, poleg njihovega nastanka ter litoloških, strukturnih, podnebnih in hidroloških značilnosti območja tudi relief oziroma natančneje naklon površja (Bahun, 1969; Čar, 1982; Čar, Šebela, 1998; Ford in Williams, 2007; Gams, 2000; 2004; Verbovšek, 2020).

$\mathrm{Na}$ krasu glede na dominanten tip preperevanja ločimo dva tipa pobočij. Na aktivnih pobočjih prevladujejo mehansko preperevanje in aktivni pobočni procesi, ki mehanski sediment premeščajo vzporedno s pobočjem navzdol. Na uravnoteženih pobočjih prevladujeta kemično preperevanje in odnašanje kamnine $\mathrm{v}$ raztopini $\mathrm{v}$ kraški vodonosnik (Stepišnik, 2010). Slednja so značilna za kraško površje, saj se zaradi odsotnosti pobočnih procesov njihova oblika, ukrivljenost in naklon bistveno ne spreminjajo. Zato se geomorfne oblike na uravnoteženih pobočjih in geomorfne oblike, ki imajo uravnotežena pobočja, kot so na primer vrtače, lahko ohranijo izjemno dolgo (Stepišnik, Kosec, 2011).

Gams (2004) je tipiziral kraška območja glede na gostote vrtač v šest tipov: izjemno visoka gostota (nad $\left.200 \mathrm{vrtač} / \mathrm{km}^{2}\right)$, zelo velika gostota $\left(120-200 \mathrm{vrtač} / \mathrm{km}^{2}\right)$, velika gostota (50-120 vrtač $\left./ \mathrm{km}^{2}\right)$, zmerna gostota $\left(15-50 \mathrm{vrtač} / \mathrm{km}^{2}\right)$, majhna gostota $\left(5-15 \mathrm{vrtač} / \mathrm{km}^{2}\right)$ in neznatna gostota (pod $\left.5 \mathrm{vrtač} / \mathrm{km}^{2}\right)$. Izjemna gostota vrtač je bila proučena na zgornjekrednih apnencih na Divaškem krasu, kjer je $240 \mathrm{vrtač} / \mathrm{km}^{2}$ (Mihevc, 2001), in na severovzhodnem obrobju Planinskega polja s 352,5 vrtačami/ $\mathrm{km}^{2}$ (Šušteršič, 1987) ter na mezozojskih apnencih in dolomitih na Skalčen kamnu z 260,8 vrtačami $/ \mathrm{km}^{2}$ (Šušteršič, 1994) in Logaškem ravniku z 243,3 vrtačami $/ \mathrm{km}^{2}$ (Mihevc, Mihevc, 2021). 
Nakloni pobočij in gostota vrtač so obratno sorazmerni (Gams, 2004; Kranjc, 1981). Kranjc (1981) je na podlagi diagrama izračunal regresijsko premico in koeficient korelacije, ki z vrednostjo -0,7638 nakazuje na močno soodvisnost in obratno sorazmernost med naklonom površja in gostoto vrtač na apnencu. Enako korelacijo med naklonom površja in gostoto ter površino vrtač sta pri proučevanju jugozahodnega dela Krasa dokazala tudi Ravbar in Zorn (2003). Frelih (2014) je največjo gostoto vrtač ugotovila na naklonih površja med 2 in $5^{\circ}$. Vrtače so na površjih z naklonom do $24^{\circ}$ (Frelih, 2014) oziroma 30-33 (Gams, 2000; Kranjc, 1972), $90 \%$ pa jih je na površju z nakloni do $20^{\circ}$ (Mihevc, Mihevc, 2021). Frelih (2014) navaja tudi, da so največje gostote vrtač na območjih, kjer so vrtače manjše in plitvejše.

Analize vrtač so postale aktualne z razvojem GIS in dostopnostjo natančnejših prostorskih podatkov (Frelih, 2014). Največ analiz je bilo opravljenih z uporabo GIS in topografskih kart različnih meril ( $1: 5.000-1: 25.000)$, vedno bolj pa se uveljavljajo tudi (pol)avtomatizirani postopki zaznavanja kotanj, ki temeljijo na interpretaciji digitalnega modela višin (DMV) in iz njega izpeljanih podatkov (senčen relief, nakloni, indeks topografske pozicije) (Fuyuan, Yunan, 2013; Miao in sod., 2013; Mihevc, 2014; Rahimi, Alexander, 2013; Verbovšek, 2020) ter na modelu hidrološko pravilnega reliefa z zapolnjevanjem kotanj (Čeru in sod., 2017; Gostinčar, 2013; Grlj, 2014; 2020; Obu, 2011; Padro-Igúzquiza in sod., 2013; Telbisz in sod., 2016; Vrbovšek, 2020).

\section{PROUČEVANA OBMOČJA}

Površje izbranih območij je razgibano, $\mathrm{z}$ različnimi nakloni pobočij, ter močno razčlenjeno z vrtačami. Poleg naklona pobočij je bil glavni dejavnik izbora območij enotna litološka sestava. Vsa območja namreč gradijo zgornjekredni apnenci (Pleničar, 1970; Šikić, Pleničar, 1975). Obenem imajo izbrana območja zmerno celinsko podnebje zahodne in južne Slovenije (Ogrin, 1996) in so brez stalnih izvirov in površinskih vodotokov.

$\mathrm{Na}$ visoki kraški planoti Hrušice, južno in vzhodno od Podkraja, je prvo proučevano območje. Obsega 7,76 km² površja in se razteza med 598 in $1108 \mathrm{~m} \mathrm{n}$. m. Na podlagi informacij o jamah $\mathrm{v}$ neposredni bližini območja, kjer je najgloblje brezno Brezno na liniji (kat. št. 4969) globoko $35 \mathrm{~m}$, ocenjujemo, da je vadozna cona na območju razvita vsaj do te globine (Kataster jam, 2021).

Drugo območje je na kraški planoti Snežnik, severno in severovzhodno od Leskove doline, na nadmorskih višinah med 729 in $936 \mathrm{~m}$ ter meri 5,03 km². Na podlagi informacij o jamah na območju, kjer je najgloblje brezno Leskovo brezno 7 (kat. št. 3681) globoko $51 \mathrm{~m}$, ocenjujemo, da je vadozna cona na območju razvita vsaj do te globine (Kataster jam, 2021).

Tretje proučevano območje je v Slavniškem pogorju, vzhodno od vrha Slavnik. Meri $3,23 \mathrm{~km}^{2}$ in se razteza med 533 in $713 \mathrm{~m} \mathrm{n}$. m. Na podlagi informacij o jamah na območju, kjer je najgloblja jama Sk 20 (Skadanščina) (kat. št. 8068) globoka 27 m, ocenjujemo, da je vadozna cona na območju razvita vsaj do te globine (Kataster jam, 2021). 


\section{MATERIALI IN METODE}

Izbor območij proučevanja je potekal s prekrivanjem slojev prostorskih podatkov DMV, geoloških kart in podatkov o povprečnih letnih temperaturah ter količinah padavin (ARSO, 2014; 2019a; 2019b; Osnovna geološka karta SFRJ, L 33-77 ..., 1967; Osnovna geološka karta SFRJ, L 33-89 ..., 1972).

$\mathrm{V}$ raziskavi smo $\mathrm{v}$ prvem koraku uporabili kombinacijo avtomatiziranih metod in zaznali vrtače. Pridobljene rezultate smo nato ročno popravili na podlagi plastnic, senčnega reliefa in podatkovnega sloja naklonov, izračunanih iz DMV (ARSO, 2014), ter rezultati terenskega kartiranja. $\mathrm{V}$ drugem koraku smo izračunali izbrane morfometrične lastnosti zaznanih vrtač ter proučili vrednosti naklonov. Za zaznavanje vrtač, izračun lastnosti in analizo rezultatov smo uporabili programa ESRI ArcMap 10.2.2 ter IDLE. Večji del postopka zaznavanja vrtač je bil opravljen z uporabo skripte, napisane v programskem jeziku Python 2.7.2 (Grlj, 2014), ki je bila za namen te raziskave popravljena v različici 2.7.5. Končna statistična analiza številčnih podatkov je bila opravljena s programom Excel.

\subsection{Zaznavanje kotanj}

Izbor vrtač je bil izveden z uporabo skripte za iskanje kraških kotanj z daljinskim zaznavanjem na podlagi rastra - vhodnega DMV (Grlj, 2014). Za analizo je bil uporabljen DMV s prostorsko ločljivostjo $1 \mathrm{~m}$ (ARSO, 2014).

Prvi korak v postopku je zapolnjevanje kotanj, ki ga skripta opravi z orodjem Fill. To zapolni kotanje $\mathrm{v}$ reliefu do višine iztoka (Pour Point), parameter Z-limit pa določa, katere kotanje bodo zapolnjene (Fill, 2021). Skripta ponovi uporabo tega orodja $\mathrm{z}$ različnimi vrednostmi $Z$-limit in na ta način zazna tudi kompleksnejše kotanje, kot so tiste, ki imajo v svojem dnu še manjše kotanje (Grlj, 2014). Za analizo smo uporabili prednastavljene parametre: začetni Z-limit (Z-limit prve ponovitve) 0,5 , končni Z-limit (Z-limit prve ponovitve) pa 10. Skripta postopek zapolnjevanja ponovi dvajsetkrat $\mathrm{z}$ intervalom 0,5 (Grlj, 2014).

V drugem koraku skripta zaznane kotanje izdvoji. To izvede na način, da od vsakega DMV z zapolnjenimi kotanjami odšteje vhodni DMV. Celice izhodnega DMV bodo imele vrednost, drugačno od nič, le na tistih območjih, kjer so bile kotanje zapolnjene (Grlj, 2014).

Dobljene rastrske sloje nato skripta z orodjem Reclassify reklasificira in jim pripiše vrednost 1 povsod, kjer je vrednost celice višja od nič. To omogoča sledečo uporabo orodja Raster to Polygon za pretvorbo v vektorske podatke (Grlj, 2014). V tem koraku smo skripto prilagodili, da dobljene poligone poenostavi (Simplify Poligons), saj zadostna prostorska ločljivost vhodnih podatkov $(1 \mathrm{~m})$ omogoča dovolj natančno poenostavitev.

V zadnjem koraku skripta $\mathrm{z}$ orodjem Merge $\mathrm{v}$ obratnem vrstnem redu združi vseh 20 vektorskih podatkovnih slojev v enega tako, da večji poligoni ne zakrijejo manjših, 
zaznanih pri nižjih vrednostih Z-limit. Na koncu skripta z uporabo orodja Delete Identical izbriše dvojnike poligonov tistih kotanj, ki so bile zaznane pri več kot eni vrednosti Z-limit, in $\mathrm{z}$ ukazom deleteRow izbriše poligone $\mathrm{z}$ vrednostjo 0 , ki so bili ustvarjeni pri vektorizaciji podatkov (Grlj, 2014).

Slika 1: Pojmovni model zaznavanja kotanj (vir: Grli, 2014).

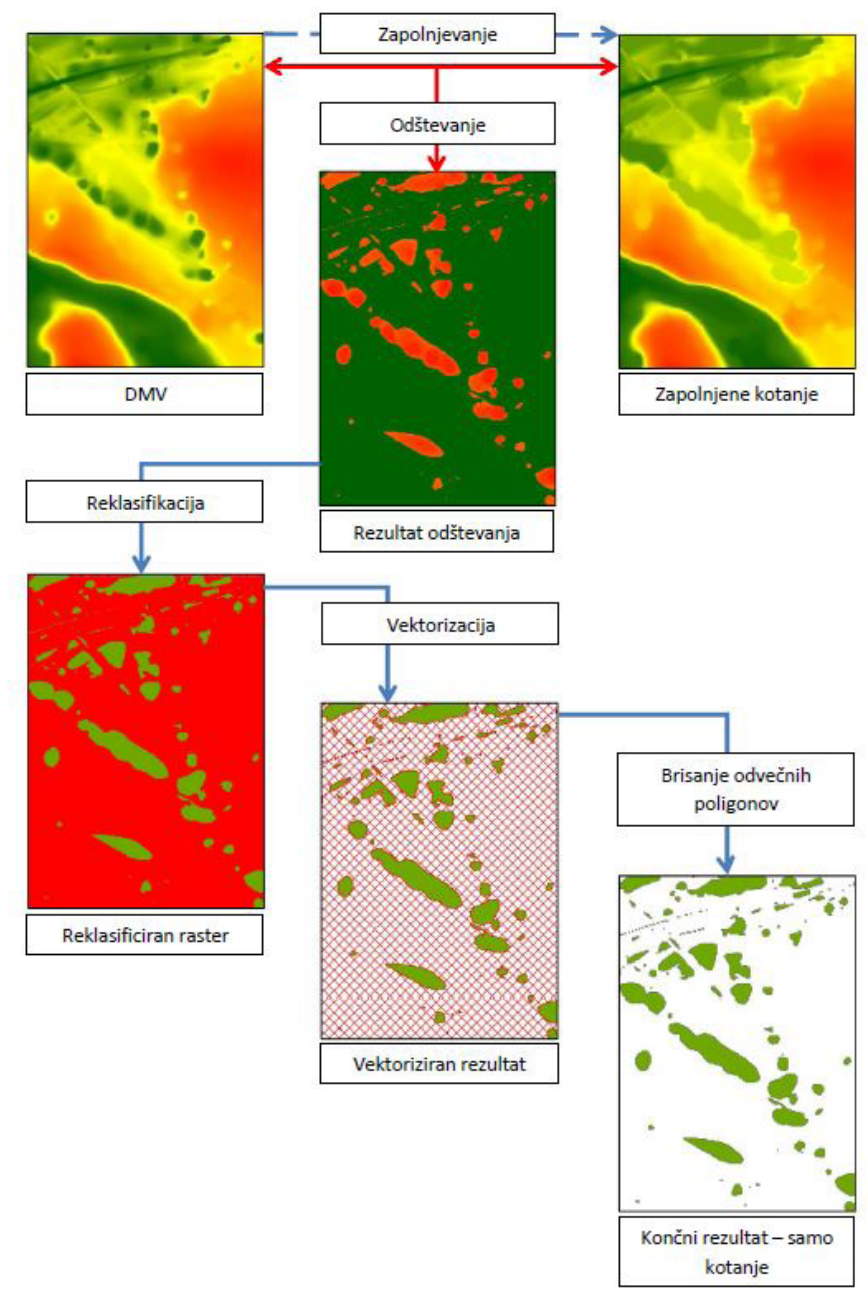

Opisana skripta dobro deluje na uravnanem reliefu in pri nizkih naklonih površja, točnost zaznavanja kotanj na pobočjih pa je omejena, saj so kotanje zapolnjene le do višine iztoka. Zaznani obod kotanje ima torej naklon $0^{\circ}$, dejanski obod pa ima enak naklon kot površje okoli njega in poteka nad zaznanim obodom, zato je posledično 
tudi drugačne oblike. Da bi odpravili to napako, smo poligone, identificirane z uporabo zgoraj opisane skripte, naknadno ročno popravili. To smo naredili z vizualno interpretacijo rezultatov na podlagi senčnega reliefa, podatkovnega sloja naklonov ter plastnic z ekvidistanco $1 \mathrm{~m}$ (ARSO, 2014), ter terenskim pregledom. Poleg tega so bili izbrisani tudi tisti poligoni, ki predstavljajo napake pri zaznavanju. Te so se pojavile zaradi previsoke natančnosti nadmorskih višin uporabljenih podatkov, na primeru vrtač na poseljenih območjih, kjer je površje antropogeno preoblikovano, ter pri nepopolnih poligonih na robovih proučevanih območij.

\subsection{Izračun in analiza lastnosti zaznanih vrtač}

Na podlagi rezultatov, ki smo jih pridobili z zaznavanjem vrtač, smo za vsako vrtačo v programu ArcMap izračunali šest morfometričnih lastnosti: tlorisna površina, obseg oboda, indeks krožnosti, dolžina krajše in daljše osi ter globina. Tlorisno površino in obseg oboda vrtač smo izračunali z uporabo orodja Calculate Geometry, ki za vsak poligon izračuna omenjeni lastnosti v izbrani merski enoti (Calculate geometry attributes, 2021). Iz podatkov o površini in obsegu smo izračunali indeks krožnosti - razmerje med površino vrtače in površino kroga $\mathrm{z}$ enakim obsegom, ki nam pove, koliko se oblika oboda posamezne vrtače približa krogu (vrednost 1).

Za izračun dolžine osi smo uporabili orodje Minimum Bounding Geometry, ki za vsak poligon v izbranem sloju ustvari nov pravokotnik glede na širino (RECTANGLE_BY_WIDTH). Dolžina njegove daljše stranice predstavlja največjo dolžino daljše osi, dolžina njegove krajše stranice pa največjo dolžino njegove krajše osi (Minimum bounding geometry, 2021).

Globino vrtač smo izračunali s pomočjo točk z najnižjo in najvišjo nadmorsko višino na območju poligona, ki smo jih določili z dvakratno ponovitvijo enakega postopka. Najprej smo z orodjem Zonal Statistics z izbiro funkcije MAXIMUM oziroma MINIMUM identificirali vrednost najvišje oziroma najnižje ležeče celice na območju poligona vrtače. Rezultat postopka je raster, ki vsem celicam na območju posameznega poligona pripiše najvišjo oziroma najnižjo vrednost $\mathrm{z}$ istega območja. Iz posameznega rastra smo nato identificirali tisto celico na DMV, ki ima omenjeno vrednost nadmorske višine s pogojnim izrazom v orodju Raster Calculator. Celica na sloju, ki je rezultat izračuna funkcije MAXIMUM oziroma MINIMUM, katere vrednost je enaka istoležeči celici izvirnega DMV, obdrži svojo vrednost, ostalim celicam pa izraz pripiše vrednost NoData. Oba rastrska sloja, ki sta rezultat tega izračuna in vsebujeta celice z vrednostmi najnižjih in najvišjih točk vseh vrtač, smo z orodjem Raster to Point pretvorili v točkovni vektorski format, pri čemer je lastnost posamezne točke njena nadmorska višina. Globino vrtač od najvišjih točk njihovih obodov do njihovih dnov smo izračunali z odštevanjem vrednosti najnižjih točk od vrednosti najvišjih točk (How to: Create points ..., 2021).

Zaradi velike razčlenjenosti površja proučevanih območij smo z uporabo orodja Focal Statistics izvorni DMV z ločljivostjo 1 m najprej »zgladili«. Za soseščino smo izbrali krog s polmerom $50 \mathrm{~m}$ (50 celic), za tip statistike pa MEAN (How focal statistics work, 2021). 
S tem smo odpravili razčlenjenost zaradi vrtač, ohranili pa splošno obliko površja. Iz teh podatkov izračunane naklone površja smo reklasificirali v sedem naklonskih razredov $0-1,9^{\circ} ; 2-5,9^{\circ} ; 6-11,9^{\circ} ; 12-19,9^{\circ} ; 20-31,9^{\circ} ; 32-54,9^{\circ}$ in več kot $55^{\circ}$. Predmet proučevanja so vrtače na pobočjih, zato naklonski razredi temeljijo na razredih analiz pobočnih procesov (Komac, 2006; Natek, 1983), ki vplivajo na morfogenezo pobočij in oblik na njih. Vrednosti posameznih naklonskih razredov smo pretvorili v vektorske podatke. Nadaljnje analize so bile opravljene znotraj posameznega naklonskega razreda. Če je vrtača hkrati na območju več naklonskih razredov, je bila obravnavana v okviru tistega, kjer je središčna točka poligona, izračunana z orodjem Feature to Point.

Za gostoto vrtač in vsako od šestih morfometričnih lastnosti (tlorisna površina, obseg oboda, indeks krožnosti, dolžina krajše in daljše osi ter globina) smo izračunali tudi Spearmanov koeficient korelacije v primerjavi z naklonom pobočja. Za vrednosti morfometričnih lastnosti smo uporabili aritmetične sredine te lastnosti za posamezni naklonski razred, za vrednosti naklona pa srednje vrednosti posameznega naklonskega razreda, $v$ katerem so vrtače: $1^{\circ}, 4^{\circ}, 9^{\circ}, 16^{\circ}$ in $26^{\circ}$. Izračun je bil narejen $\mathrm{z}$ uporabo funkcije CORREL v programu Excel.

\section{REZULTATI}

Slika 2: Karta naklonskih razredov in vrtač, obravnavanih $\checkmark$ posameznem razredu, na območju Hrušice.

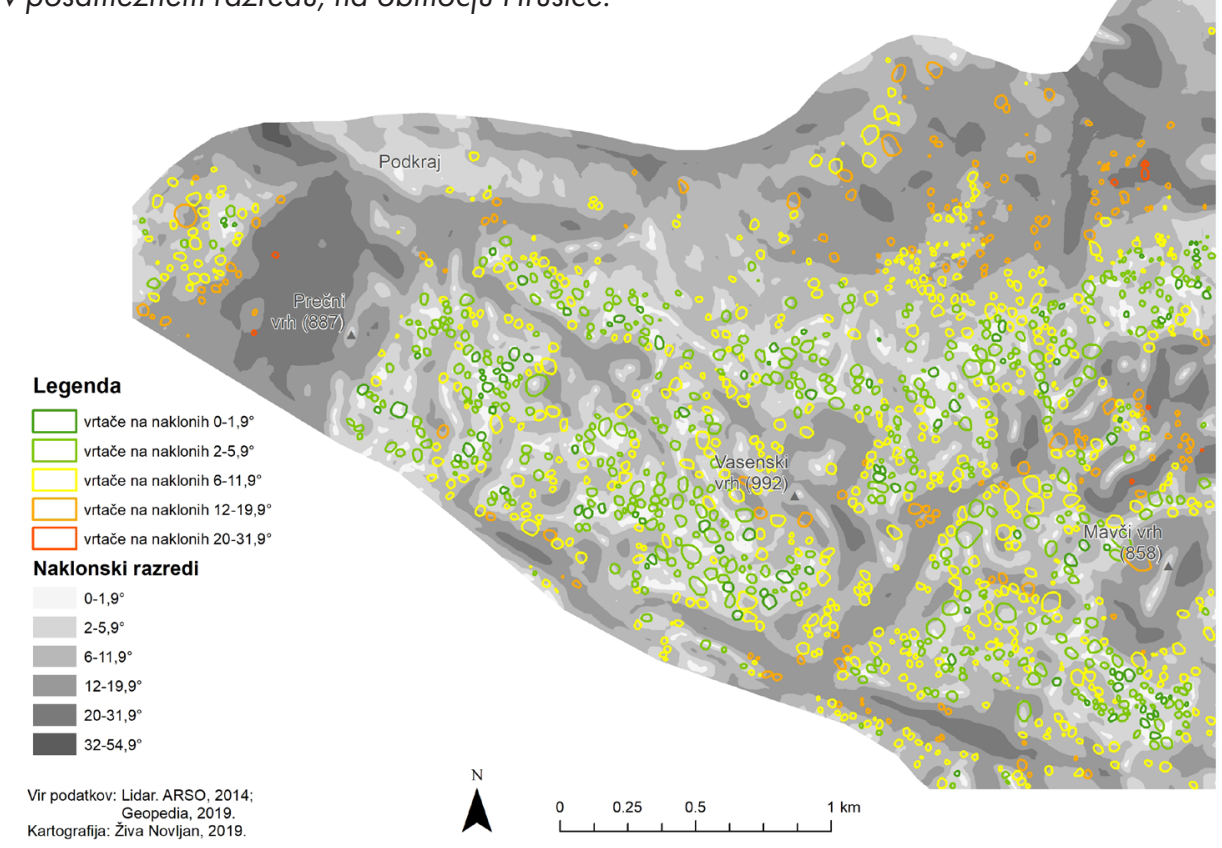


Slika 3: Karta naklonskih razredov in vrtač, obravnavanih $v$ posameznem razredu, na območju Snežnika.

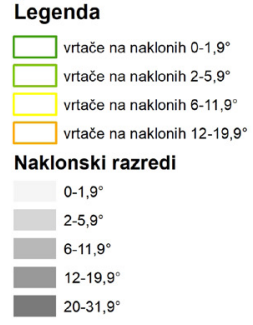

Vir podatkov: Lidar. ARSO, 2014; Keopedia, 2019.

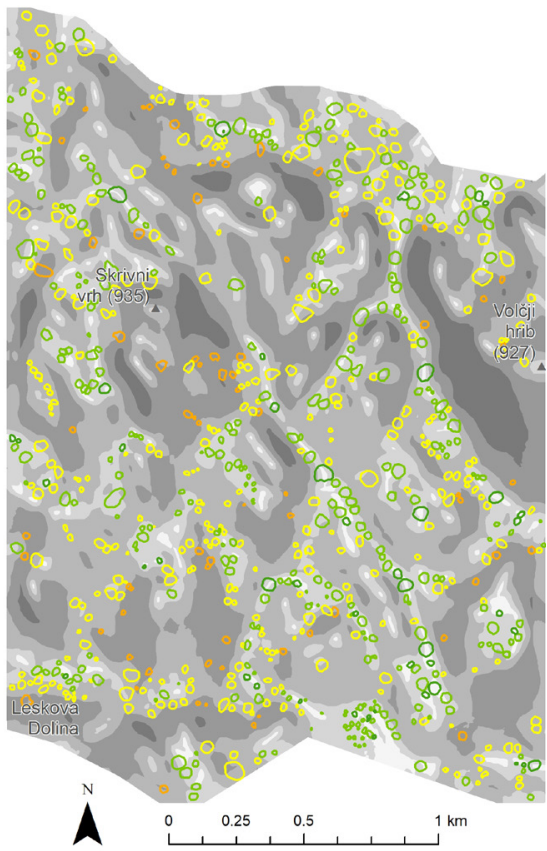

Slika 4: Karta naklonskih razredov in vrtač, obravnavanih $v$ posameznem razredu, na območju Slavnika.

\section{Legenda}

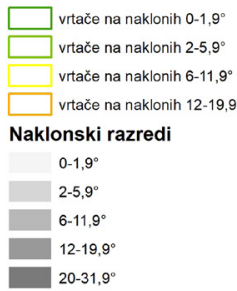

Vir podatkov: Lidar. ARSO, 2014 Kartografija: Živa Novlian, 2019.

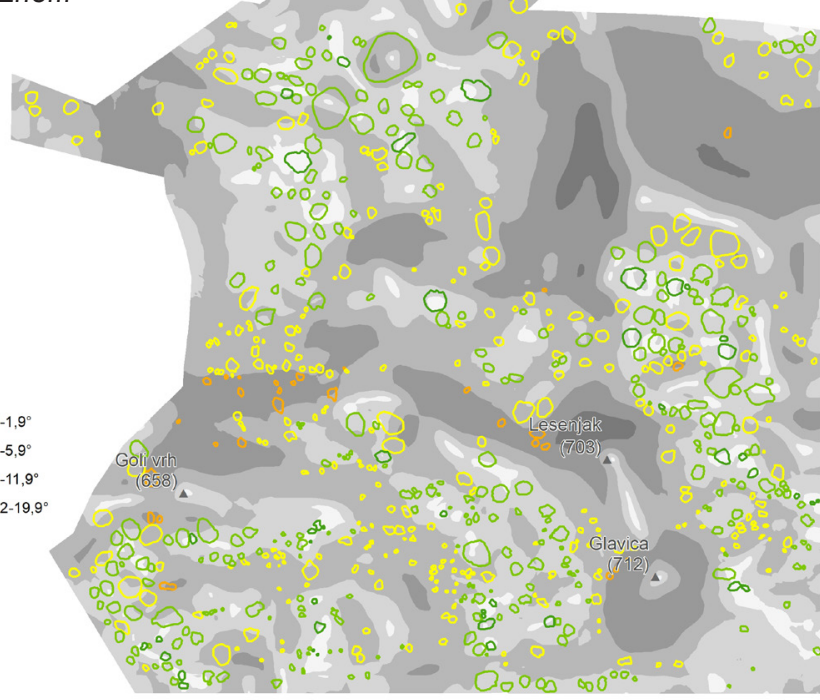

$\Lambda$

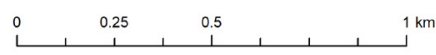


Izračunane vrednosti morfometričnih lastnosti smo proučili za celotno množico proučevanih vrtač ter glede na njihovo pripadnost naklonskim razredom ter proučevanim območjem.

Na vseh treh proučevanih območjih smo zaznali 2805 vrtač, od tega 1363 na območju Hrušice, 780 na območju Snežnika in 680 na območju Slavnika. Na vseh treh proučevanih območjih se nakloni pobočij razvrstijo $\mathrm{v}$ prvih petih naklonskih razredih do $31,9^{\circ}$, na Hrušici pa manjši del proučevanega območja pripada tudi naklonskemu razredu $32-54,9^{\circ}$. Največjo gostoto vrtač na vseh območjih skupaj smo izračunali v prvih dveh naklonskih razredih med 0 in $1,9^{\circ}\left(323,3 \mathrm{vrtač} / \mathrm{km}^{2}\right)$ in med 2 in 5,9 $\left(268,2 \mathrm{vrtač} / \mathrm{km}^{2}\right)$. Sledi naklonski razred med 6 in $11,9^{\circ}\left(188,6 \mathrm{vrtač} / \mathrm{km}^{2}\right)$, zatem pa gostota znatno pade in je $67,5 \mathrm{vrtač} / \mathrm{km}^{2}\left(12-19,9^{\circ}\right)$. Na naklonih med 20 in $31,9^{\circ}$ smo vrtače zaznali le na območju Hrušice, vendar je tudi tu njihova gostota izjemno nizka $\left(15,2 \mathrm{vrtač} / \mathrm{km}^{2}\right)$. Koeficient korelacije med naklonom pobočja in gostoto vrtač je $-0,9755$, torej sta spremenljivki obratno sorazmerni.

Slika 5: Gostota vrtač na proučevanih območjih glede na naklonske razrede.

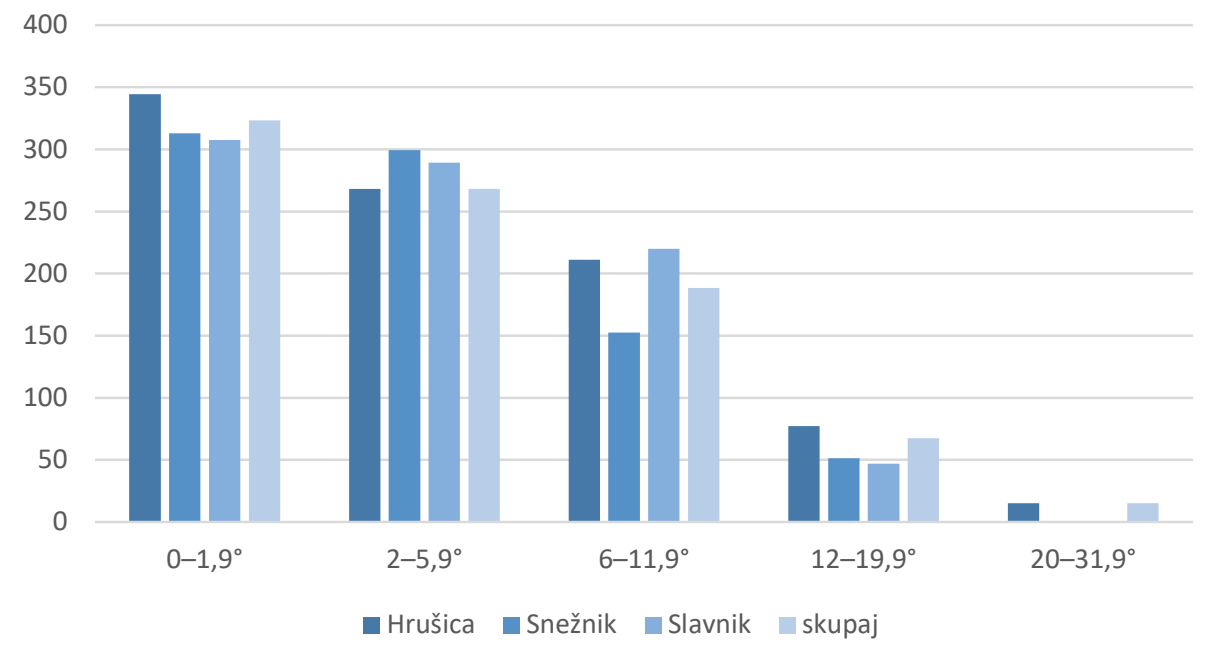

Povprečna vrtača ima površino $552,7 \mathrm{~m}^{2}$, je globoka $6,5 \mathrm{~m} \mathrm{z}$ obsegom oboda 78,4 $\mathrm{m}$, dolžino krajše osi $21,1 \mathrm{~m}$, dolžino daljše osi $27,5 \mathrm{~m}$ in indeksom krožnosti 0,88 . Na Hrušici imajo vrtače najvišje vrednosti morfometričnih lastnosti, na Snežniku srednje, na Slavniku pa najmanjše vrednosti. Povprečni obod vrtač na Hrušici $(0,90)$ se najbolj približa pravilni krožni obliki, sledijo vrtače na Snežniku $(0,89)$, v povprečju najmanj pravilne krožne oblike pa so vrtače na Slavniku $(0,84)$. 
Preglednica 1: Povprečne vrednosti morfometričnih lastnosti vrtač glede na proučevano območje.

\begin{tabular}{|l|c|c|c|c|}
\hline & Hrušica & Snežnik & Slavnik & skupaj \\
\hline $\mathrm{N}$ & 1363 & 762 & 680 & 2805 \\
\hline površina $\left[\mathrm{m}^{2}\right]$ & 597,0 & 570,0 & 444,7 & 552,7 \\
\hline globina [m] & 7,0 & 6,7 & 5,2 & 6,5 \\
\hline krajša os [m] & 22,4 & 21,6 & 17,8 & 21,1 \\
\hline daljša os [m] & 29,2 & 27,6 & 24,1 & 27,5 \\
\hline obseg [m] & 82,8 & 80,5 & 67,4 & 78,4 \\
\hline indeks krožnosti [/] & 0,90 & 0,89 & 0,84 & 0,88 \\
\hline
\end{tabular}

Vrednosti štirih morfometričnih lastnosti vrtač, ki temeljijo na tlorisu vrtače (površina, obseg ter dolžini krajše in daljše osi), se zmanjšujejo z naraščanjem naklona pobočja. Kljub temu pa razmerje med krajšimi in daljšimi osmi in posledično indeks krožnosti ostajata približno enaka pri vseh naklonih pobočij $(0,88-0,89)$. Globina analiziranih vrtač se povečuje s povečevanjem naklona pobočja, povezanost teh dveh spremenljivk pa je zelo močna $(0,9766)$.

Preglednica 2: Povprečne vrednosti morfometričnih lastnosti vrtač glede na naklon površja.

\begin{tabular}{|l|c|c|c|c|c|}
\hline & $\mathbf{0 - 1 , \mathbf { 9 } ^ { \circ }}$ & $\mathbf{2 - 5 , 9 ^ { \circ }}$ & $\mathbf{6 - 1 1 , 9 ^ { \circ }}$ & $\mathbf{1 2 - 1 9 , 9}^{\circ}$ & $\mathbf{2 0 - 3 1 , 9 ^ { \circ }}$ \\
\hline $\mathrm{N}$ & 193 & 1085 & 1244 & 274 & 9 \\
\hline površina $\left[\mathrm{m}^{2}\right]$ & 645,1 & 601,4 & 515,0 & 479,0 & 252,7 \\
\hline globina $[\mathrm{m}]$ & 6,2 & 6,3 & 6,5 & 7,4 & 7,9 \\
\hline krajša os [m] & 22,9 & 22,2 & 20,4 & 18,9 & 14,4 \\
\hline daljša os [m] & 29,9 & 29,0 & 26,5 & 25,1 & 19,6 \\
\hline obseg [m] & 85,9 & 81,9 & 75,9 & 72,0 & 55,6 \\
\hline indeks krožnosti $[/]$ & 0,89 & 0,88 & 0,88 & 0,88 & 0,89 \\
\hline
\end{tabular}

\section{DISKUSIJA}

Vrtače so kot najbolj tipične in pogoste površinske kraške reliefne oblike zmernih geografskih širin (Sweeting, 1972) predmet številnih raziskav. Namen raziskave je bil proučiti gostoto vrtač ter njihove morfometrične lastnosti v odvisnosti od naklona pobočja.

Gostota vrtač na proučevanih območjih te raziskave je glede na opredelitev Gamsa (2004) v povprečju vseh naklonskih razredov zelo visoka $\left(175,1 \mathrm{vrtač} / \mathrm{km}^{2}\right)$, na naklonih 
pobočij do $5,9^{\circ}$ pa celo izjemna (323,3 oziroma $\left.268,2 \mathrm{vrtač} / \mathrm{km}^{2}\right)$. To potrjuje ugotovitve Kranjca (1981) na Ribniški Mali gori, Ravbar in Zorna (2003) na jugozahodnem delu Krasa ter Frelih (2014) na različnih vrstah krasa na območju Slovenije. Ti so največje gostote vrtač na svojih proučevanih območjih izmerili na površju z nakloni do $5^{\circ}$. Na naklonih med 6 in $11,9^{\circ}$ je gostota še zelo visoka $\left(188,6 \mathrm{vrtač} / \mathrm{km}^{2}\right)$, zatem pa znatno pade. Izračunani koeficient korelacije med naklonom pobočja in gostoto vrtač $(-0,9755)$ potrjuje obratno sorazmerje med tema dvema spremenljivkama in kaže na še močnejšo povezanost, kot jo je izračunal Kranjc (1981) na Ribniški Mali gori (-0,7638).

Vrtače na naklonih med 20 in $31,9^{\circ}$ smo izmed proučevanih območij zaznali le na Hrušici, tudi tam pa je njihova gostota zelo nizka $\left(15,18 \mathrm{vrtač} / \mathrm{km}^{2}\right)$. To potrjuje navedbe Kranjca (1981) in Gamsa (2000), da so v Sloveniji vrtače na pobočjih z nakloni do 30 oziroma $33^{\circ}$. Po podrobnejšem pregledu smo ugotovili, da so vse vrtače na pobočjih z nakloni do $24^{\circ}$, s čimer smo nadalje potrdili enake ugotovitve Frelih (2014). Vrtače so torej oblikovane na uravnoteženih pobočjih, kjer se izenačita mehansko in kemično preperevanje ali pa celo prevlada kemično preperevanje kamnine. To omogoča, da se geomorfne oblike tam ohranijo dlje (Stepišnik, Kosec, 2011).

$S$ primerjavo vrednosti gostote ter površine in globine vrtač lahko potrdimo ugotovitve Frelih (2014), da so največje gostote vrtač tam, kjer so vrtače najmanjše in najplitvejše. Povprečna gostota vrtač na Slavniku je namreč $210,5 \mathrm{vrtač} / \mathrm{km}^{2}$, kar je največ izmed vseh treh proučevanih območij. Kljub temu pa ne moremo trditi, da obstaja obratno sorazmerje med gostoto in dimenzijami vrtač, kot trdi Frelih (2014), saj imajo drugo največjo gostoto vrtače na Hrušici, ki pa so v povprečju največje.

Proučena literatura (Ford, Williams, 2007; Jennings, 1971) navaja, da lega vrtač na pobočjih povzroča asimetrično obliko vrtač. Te naj bi bile podaljšane v smeri pobočja, s položnejšim višjim pobočjem. Na podlagi naših rezultatov lahko to trditev ovržemo. Poleg ugotovitve, da se krožnost tlorisa vrtače ne spreminja $z$ naklonom pobočja, smo ob zaznavanju vrtač ugotovili, da je višje pobočje vrtače praviloma tudi bolj strmo. Med raziskavo smo opazili tudi, da med analiziranimi vrtačami ni prevladujoče usmeritve daljše osi vrtač v smeri padanja pobočja. Iz tega sklepamo, da ima večji vpliv na njihovo orientacijo od naklona površja geološka struktura, ki jo izpostavljajo Bahun (1969), Čar (1982) in Frelih (2014).

Proučeni podatki globine vrtač, ki se spreminja premo sorazmerno $\mathrm{z}$ naklonom pobočja, nakazujejo na morebitno bolj intenzivno poglabljanje na pobočjih z višjim naklonom ter na širjenje vrtač na bolj položnih pobočjih oziroma uravnavah. Tega vseeno ne moremo trditi z gotovostjo, saj pri naši raziskavi nismo upoštevali strukturnih elementov matične podlage, ki vplivajo na hitrost kemičnega in mehanskega preperevanja kamnine, ter debeline prepereline. Habič (1978) sicer navaja, da so starejše vrtače navadno globlje, vendar tudi te trditve na podlagi naše analize ne moremo niti potrditi niti ovreči, saj podatkov o starosti vrtač na tem območju nimamo.

Rezultati raziskave dajejo splošno sliko o odvisnosti gostote in morfologije vrtač od naklona površja, za natančnejše rezultate pa bi bilo treba odpraviti nekatere 
pomanjkljivosti, ki smo jih zaznali. Zaradi odsotnosti popolnoma avtomatizirane metode zaznavanja vrtač, ki izloči človekovo presojo kot subjektivni dejavnik zaznavanja, bi ob ponovitvi raziskave verjetno prišli do drugačnih absolutnih vrednosti posameznih lastnosti. Opiranje na več različnih podatkovnih slojev v kombinaciji s terenskim delom to možnost zmanjšuje, vendar je ne odstrani popolnoma. Poleg tega smo zaradi različne velikosti posameznih proučevanih območij na njih zaznali različno število vrtač. Glede na to, da se vrtače po povprečnih dimenzijah na posameznih območjih nekoliko razlikujejo, bi bilo smiselno $\mathrm{z}$ uporabo uteži izenačiti njihov vpliv na izračun skupnih povprečnih vrednosti parametrov glede na površino območja. Kljub temu menimo, da so relativne vrednosti in povezave med posameznimi spremenljivkami dovolj točne za argumentacijo naših ugotovitev. Natančnejšo obliko vrtač v živoskalni podlagi bi lahko določali $\mathrm{z}$ analizo električne prevodnosti tal, s čimer bi zmanjšali vpliv prepereline na dojemanje oblike vrtač. $S$ temi podatki ter podrobnejšo analizo strukturnih lastnosti območja in usmerjenosti daljše osi vrtače glede na smer padanja pobočij bi lahko nadalje raziskali odvisnost asimetrije vrtač od različnih dejavnikov.

Zaključimo lahko, da se gostota in morfometrične lastnosti vrtač spreminjajo $\mathrm{v}$ odvisnosti od naklona pobočja. Vrtače so oblikovane na uravnoteženih pobočjih, v primeru naše raziskave do naklona $24^{\circ}$, njihova gostota pa pada obratno sorazmerno z naraščanjem naklona površja. Povprečna površina, obseg ter dolžini osi se z naraščanjem naklona zmanjšujejo, globina pa se povečuje. Indeks krožnosti ostaja približno enak, ne glede na naklon pobočja. Zaznali smo tudi, da usmeritev daljše osi vrtače ni odvisna od usmeritve pobočja, kar pomeni, da nanjo bolj verjetno vpliva struktura matične podlage.

\section{SKLEPI}

Vrtače, najbolj tipične in pogoste reliefne oblike kraškega površja zmernih geografskih širin, so kotanje z bolj ali manj pravilnim krožnim obodom in konkavnim profilom ter različnih dimenzij, značilno pa je, da je premer njihovega oboda večji od njihove globine (Gams, 2004; Sauro, 2012). V preteklih raziskavah je bilo ugotovljeno, da se vrtače ne nahajajo na pobočjih z naklonom nad $24^{\circ}$ (Frelih, 2014) oziroma 30-33 (Gams, 2000; Kranjc, 1981) njihova gostota pa je največja na pobočjih z nakloni do $5^{\circ}$. DMV je osnova za analize vrtač z GIS orodji, ki tudi z različnimi izpeljavami, na primer plastnicami, senčnim reliefom in nakloni, omogoča natančno zaznavo vrtač, GIS pa nam omogoča hitro obdelavo večje količine podatkov in izračun morfometričnih lastnosti vrtač (Frelih, 2014).

Na območju slovenskega krasa smo na podlagi primerljivih relevantnih fizičnogeografskih značilnosti izbrali tri območja proučevanja. Glavna kriterija sta bila litološka sestava in naklon površja. Prvi dve območji sta na pobočjih visokih kraških planot Hrušice in Snežnika, tretje pa v Slavniškem pogorju. Izbrana območja sestavljajo 
zgornjekredni apnenci (Pleničar, 1970; Šikić, Pleničar, 1975) in imajo zmerno celinsko podnebje zahodne in južne Slovenije (Ogrin, 1996).

Za zaznavanje vrtač smo uporabili kombinacijo avtomatiziranega daljinskega zaznavanja in vizualne interpretacije podatkov, pri čemer so bili rezultati prvega, avtomatiziranega postopka uporabljeni kot osnova za vizualno interpretacijo. Avtomatizirani postopek je del metode, ki jo je z namenom zaznavanja brezstropih jam razvil Grlj (2014). Obsega ponavljajoče zapolnjevanje kotanj na DMV do višine iztoka in odštevanje novonastalega DMV od izvirnega. Raster, ki je rezultat tega odštevanja, vsebuje le območja vrtač. Tako zaznamo kotanje na več nivojih (Grlj, 2014). Dobljene vektorske rezultate smo nato ročno popravili $\mathrm{z}$ vizualno interpretacijo površja na podlagi sloja plastnic, naklonov površja in senčnega modela reliefa, izpeljanih iz izvirnega DMV, ter terenskega pregleda. Vsem tako zaznanim vrtačam smo nato izračunali vrednosti površine, globine, obsega, dolžine krajše in daljše osi ter indeks krožnosti. Za nekoliko generalizirano obliko površja smo izračunali vrednosti naklonov pobočij, ki smo jih razdelili v 7 razredov: $0-1,9^{\circ} ; 2-5,9^{\circ} ; 6-11,9^{\circ} ; 12-19,9^{\circ} ; 20-31,9^{\circ}$; $32-54,9^{\circ}$ in več kot $55^{\circ}$, vrtače pa smo sicer zaznali le na območju prvih petih. $Z$ uporabo opisne statistike smo analizirali gostoto in morfometrijo vrtač znotraj vsakega od naklonskih razredov.

V raziskavi smo analizirali morfometrične lastnosti 2805 vrtač. Skupna povprečna gostota vrtač je $175,1 \mathrm{vrtač} / \mathrm{km}^{2}$. Najvišja povprečna gostota vrtač je bila izmerjena na območjih z naklonom med 0 in $1,9^{\circ}\left(323,3\right.$ vrtač $\left./ \mathrm{km}^{2}\right)$, najnižja pa na območjih z nakloni površja med 20 in $31,9^{\circ}\left(12,58 \mathrm{vrtač} / \mathrm{km}^{2}\right)$. Izjemno visoko gostoto vrtač smo izmerili tudi na območjih z nakloni med 2 in $5,9^{\circ}$. Koeficient korelacije med naklonom pobočja in gostoto vrtač je $-0,9755$ in nakazuje obratno sorazmerje med tema spremenljivkama. $\mathrm{Za}$ analizo morfometričnih lastnosti vrtač smo izbrali površino, globino, dolžino osi, indeks krožnosti in obseg oboda. Povprečna vrtača ima površino $552,7 \mathrm{~m}^{2}$, je globoka $6,5 \mathrm{~m} \mathrm{z}$ obsegom oboda $78,4 \mathrm{~m}$, dolžino krajše osi $21,1 \mathrm{~m}$, dolžino daljše osi $27,5 \mathrm{~m}$ in indeksom krožnosti 0,88 . Površina, obseg ter dolžini krajše in daljše osi vrtače so zelo močno obratno sorazmerni $z$ naklonom pobočja, indeks krožnosti pa ne glede na naklon ostaja približno enak $(0,88-0,89)$. Globina analiziranih vrtač se spreminja premo sorazmerno z naklonom pobočja (koeficient korelacije 0,9766 ).

Ugotavljamo, da se gostota in morfometrične lastnosti vrtač spreminjajo v odvisnosti od naklona pobočja, na katerem se te vrtače nahajajo. Najvišje gostote vrtač so na pobočjih $\mathrm{z}$ nakloni do $5^{\circ}$. Vrtače so oblikovane na uravnoteženih pobočjih do naklona $24^{\circ}$, njihova gostota pa pada obratno sorazmerno $\mathrm{z}$ naraščanjem naklona površja. Povprečna površina, obseg ter dolžini osi se z naraščanjem naklona zmanjšujejo. Nasprotno se globina vrtač z večanjem naklona povečuje. Indeks krožnosti ostaja približno enak, ne glede na naklon pobočja. Opazili smo tudi, da je višje pobočje vrtače praviloma bolj strmo in da usmeritev daljše osi vrtače ni odvisna od usmeritve pobočja. Iz slednjega sklepamo, da nanjo bolj verjetno vpliva struktura matične podlage. 


\section{Literatura in viri}

ARSO [Agencija Republike Slovenije za okolje], 2014. Lidar. URL: http://gis.arso.gov. si/evode/profile.aspx?id=atlas_voda_Lidar@Arso (citirano 5.4.2019).

ARSO, 2019a. Povprečna letna temperatura zraka 1971-2000. URL: http://gis.arso. gov.si/wfs_web/faces/WFSLayersList.jspx (citirano 21.4. 2019).

ARSO, 2019b. Povprečna letna višina korigiranih padavin 1971-2000. URL: http:// gis.arso.gov.si/wfs_web/faces/WFSLayersList.jspx (citirano 21. 4. 2019).

Bahun, S., 1969. On the formation of dolines. Geološki vjesnik, 22, str. 25-32.

Calculate geometry attributes. ESRI. URL: https://pro.arcgis.com/en/pro-app/toolreference/data-management/calculate-geometry-attributes.htm (citirano 18. 9. 2021).

Čar, J., 1982. Geološka zgradba požiralnega obrobja Planinskega polja. Acta Carsologica, 10, str. 75-105.

Čar, J., Šebela, S., 1998. Bedding planes, moved bedding planes, connective fissures and horizontal cave passages (Examples from Postojna jama cave). Lezike, zdrsne lezike, vezne razpoke in horizontalni rovi (primeri iz Postojnske jame). Acta Carsologica, 27, 2, str. 75-95.

Čeru, T., Šegina, E., Gosar, A., 2017. Geomorphological dating of pleistocene conglomerates in Central Slovenia based on spatial analyses of dolines using LiDAR and ground penetrating radar. Remote Sensing, 9, 12, str. 1213-1237. DOI: 10.3390/ rs9121213.

Digitalni model višin. Portal prostor. GURS. 2017. URL: https://www.e-prostor. gov.si/zbirke-prostorskih-podatkov/topografski-in-kartografski-podatki/digitalni-model-visin/digitalni-model-visin-z-locljivostjo-dmv-125-dmv-25-dmv-100/\#tab2-1046 (citirano 20. 11. 2021).

Fill. ESRI. URL: http://desktop.arcgis.com/en/arcmap/10.3/tools/spatial-analysttoolbox/fill.htm (citirano 18. 9. 2021).

Ford, D. C., Williams, P. W., 2007. Karst hydrogeology and geomorphology. Chichester: John Wiley \& Sons.

Frelih, M., 2014. Gostota, razporeditev in morfološke značilnosti vrtač na izbranih primerih v Sloveniji. Doktorska disertacija. Ljubljana: Filozofska fakulteta, Oddelek za geografijo.

Fuyuan, L., Yunan, D., 2013. An automated method to extract typical karst landform entities from contour lines on topographic maps. URL: http://www.geomorphometry.org/system/files/LiangDu2013geomorphometry.pdf (citirano 30. 4. 2018).

Gams, I., 2000. Doline morphogenetic processes from global and local viewpoints. Acta Carsologica, 29, 2, str. 123-138.

Gams, I., 2004. Kras v Sloveniji v prostoru in času. Ljubljana: Založba ZRC, ZRC SAZU.

Gostinčar, P., 2013. The application of GIS methods in morphometrical analysis of dolines on limestone and dolomite bedrock. V: Michail, F., Bosak, P. (ur.). Proceedings of the 16th international congress of speleology. Brno, International Union of Speleology, Czech Speleological Society, str. 84-88. 
Grlj, A., 2014. Uporaba digitalnega modela višin in izbranih večspektralnih izdelkov daljinskega zaznavanaja za iskanje kraških kotanj in brezstropih jam Podgorskega krasa. Magistrsko delo. Ljubljana: Filozofska fakulteta, Oddelek za geografijo.

Grlj, A., 2020. Omejevanje kraških kotanj z analizo polrezov. Dela, 53, str. 5-22. DOI: 10.4312/dela.53.5-22.

Habič, P., 1978. Razporeditev kraških globeli v Dinarskem krasu. Geografski vestnik, 50 , str. $17-31$.

How focal statistics work. ESRI. URL: http://desktop.arcgis.com/en/arcmap/10.3/tools/spatial-analyst-toolbox/how-focalstatistics-works.htm (citirano 18. 9. 2021).

How to: Create points representing the highest or lowest elevations within polygon features. ESRI. URL: https://support.esri.com/en/technical-article/000011761 (citirano 18. 9. 2021).

Jennings, J. N., 1971. Karst. Cambridge: The M. I. T. Press.

Kataster jam. Jamarska zveza Slovenije. 2021. URL: https://kataster.jamarska-zveza.si/ (citirano 24. 12. 2021).

Komac, B., 2006. Dolec kot značilna oblika dolomitnega površja. Ljubljana: Založba ZRC.

Kranjc, A., 1972. Kraški svet Kočevskega polja in izraba njegovih tal. Geografski zbornik, 13, str. 129-159.

Kranjc, A., 1981. Prispevek k poznavanju razvoja krasa v Ribniški Mali gori. Acta Carsologica, 9, str. 26-85.

Miao, X., Qiu, X., Wu, S.-S., Luo, J., Gouzie, D. R., Xie, H., 2013. Developing efficient procedures for automated sinkhole extraction from Lidar DEMs. Photogrammetric Engineering \& Remote Sensing, 79, 6, str. 545-554. DOI: 10.14358/PERS.79.6.545.

Mihevc, A., 2001. Speleogeneza Divaškega krasa. Ljubljana: Založba ZRC SAZU.

Mihevc, A., Mihevc, R., 2021. Morphological characteristics and distribution of dolines in Slovenia, a study of a lidar-based doline map of Slovenia. Acta Carsologica, 50, 1, str. 11-36. DOI: 10.3986/ac.v50i1.9462.

Mihevc, R., 2014. Kraške vrtače Dinarskega krasa. Diplomsko delo. Ljubljana: Fakulteta za matematiko in fiziko, Oddelek za fiziko.

Minimum bounding geometry. ESRI. URL: http://desktop.arcgis.com/en/ar$\mathrm{cmap} / 10.3 /$ tools/data-management-toolbox/minimumbounding-geometry.htm (citirano 18. 9. 2021).

Natek, K., 1983. Metoda izdelave in uporabnost splošne geomorfološke karte. Magistrsko delo. Ljubljana: Filozofska fakulteta, Oddelek za geografijo.

Obu, J., 2011. Prepoznavanje kraških kotanj na podlagi digitalnega modela višin. Diplomsko delo. Ljubljana: Filozofska fakulteta, Oddelek za geografijo.

Ogrin, D., 1996. Podnebni tipi v Sloveniji. Geografski vestnik, 68, str. 39-56.

Osnovna geološka karta SFRJ, L 33-77, Postojna. Osnovna geološka karta. 1967. 1 : 100.000. Beograd, Zvezni geološki zavod.

Osnovna geološka karta SFRJ, L 33-89, Ilirska Bistrica. Osnovna geološka karta. 1972. $1: 100.000$. Beograd, Zvezni geološki zavod. 
Padro-Igúzquiza, E., Durán, J. J., Dowd, P. A., 2013. Automatic detection and delineation of karst terrain depressions and its application in geomorphological mapping and morphometric analysis. Acta Carsologica, 42, 1, str. 17-24. DOI: 10.3986/ac. v42i1.637.

Pleničar, M., 1970. Tolmač za list Postojna. Beograd, Zvezni geološki zavod, 62 str.

Radinja, D., 1969. Doberdobski kras. Morfogenetska problematika robne kraške pokrajine. Geografski zbornik, 11, str. 225-278.

Rahimi, M., Alexander, E. C., 2013. Locating sinkholes in lidar coverage of a glaciofluvial karst, Winona county, MN. V: Land, L., Doctor, H. D., Staphenson, J. B. (ur.). Sinkholes and the engineering and anvironmental impacts of karst. Carlsbad: National Cave and Karst Research Institute, str. 469-480.

Ravbar, N., Zorn, M., 2003. Some characteristics of dolines on the Kras plateau in southwestern Slovenia. Geomorphologia Slovaca, 3, 2, str. 64-72.

Sauro, U., 2012. Closed depressions in karst areas. V: White, W. B., Culved, D. C. (ur.). Encyclopedia of caves. Waltham: Academic Press, str. 140-152.

Stepišnik, U. 2010. Udornice v Sloveniji. Ljubljana: Znanstvena založba Filozofske fakultete. URL: http://www.dlib.si/details/URN:NBN:SI:doc-LJJENT61 (citirano 24. 4. 2018).

Stepišnik, U., Kosec, G., 2011. Modelling of slope processes on karst. Acta Carsologica, 40, 2, str. 267-273. DOI: 10.3986/ac.v40i2.11.

Sweeting, M. M., 1972. Karst landforms. London: Macmillan.

Šikić, D., Pleničar, M., 1975. Tumač za list Ilirska Bistrica. Beograd: Zvezni geološki zavod.

Šušteršič, F., 1987. Drobno kraško površje ob severovzhodnem obrobju Planinskega polja. Acta Carsologica, 16, str. 51-82

Šušteršič, F., 1994. Classic dolines of classical site. Acta Carsologica, 23, str. 123-154.

Telbisz, T., Latos, T., Deak, M., Szekely, B., Koma, S., Standovar, T., 2016. The advantage of lidar digital terrain models in doline morphometry compared to topographic map based datasets - Aggtelek karst (Hungary) as an example. Acta Carsologica, 45, 1, str. 5-18. DOI: 10.3986/ac.v45i1.4138.

Verbovšek, T., 2020. Prostorska statistika globin vrtač na Matarskem podolju z metodo Getis-Ord. V: Ciglič, R. in sod. (ur.). Modeliranje pokrajine. Ljubljana: Založba ZRC SAZU, str. 9-18. DOI: 10.3986/9789610504696.

Waltham, A. C., Fookes, P. G., 2003. Engineering classification of karst ground conditions. Quarterly Journal of Engineering Geology and Hydrogeology, 36, str. 101-118. 


\section{MORPHOMETRY AND DENSITY OF DOLINES ON SLOPES OF SLOVENIAN KARST}

\section{Summary}

A doline, the most typical and common surface form on mid-latitude karst, is a depression with a more or less regular circular perimeter and a concave profile that can have different dimensions, but typically the diameter of its perimeter is larger than its depth (Gams, 2004; Sauro, 2012). In addition to the genetic process, the shape and frequency of dolines are also influenced by various spatial factors - geological, climatic, and hydrological characteristics of the area, as well as relief, more specifically the slope of the surface on which they occur (Čar, Šebela, 1998; Ford, Williams, 2007; Gams, $2000 ; 2004)$. Previous studies have shown that dolines do not occur on slopes with inclinations greater than $24^{\circ}$ (Frelih, 2014) or 30-33 (Gams, 2000; Kranjc, 1981). 90\% of all dolines occur on slopes with the inclination up to $20^{\circ}$ (Mihevc, Mihevc, 2021) and that they occur most densely on slopes with inclinations up to $5^{\circ}$ (Frelih, 2014).

The digital elevation model (DEM) provides the basis for doline analysis using GIS and enables accurate detection of dolines using various derivatives (e.g., contours, shaded relief, slope) as well as rapid processing of large amounts of data and calculation of morphometric parameters. The accuracy of the detection depends mainly on the accuracy of the data, especially on the spatial resolution. Lidar data can be used to create DEM with spatial resolution of 1 metre, which was also done for the purpose of this research.

Three areas in the Slovenian karst with comparable physical-geographical characteristics were selected for this study, the main criteria being lithology and surface slope inclination. The first two areas are located on the high karst plateaus of Hrušica and Snežnik, while the third is located on the Slavnik hill range. The areas lie between 533 and $1108 \mathrm{~m}$ above sea level and have a cumulative area of $16.02 \mathrm{~km}^{2}$. They consist of early Cretaceous limestones (Osnovna geološka karta SFRJ, L 33-77..., 1967; Osnovna geološka karta SFRJ, L 33-89..., 1972; Pleničar, 1970; Šikić, Pleničar, 1975) and have a temperate continental climate in western and southern Slovenia (Ogrin, 1996).

A combination of automated detection and visual interpretation of the data was used to identify dolines on these plots, using the results of the first, automated process as the basis for the visual interpretation. The automated process is a part of a method, developed by Grlj (2014). It consists of the repetitive process of filling sinks on DEM up to the pour point and subtracting the new DEM from the original. The result contains only the areas of dolines. This method can be used to detected the depressions on many levels (Grlj, 2014). The results in vector format were then manually corrected with the visual interpretation of the surface, using contour, slope and shaded relief data derived from the original DEM, as well as the data obtained through a 
field survey. The area, depth, perimeter, shorter and longer axis length, and circularity index were calculated for all the identified dolines. The surface slope inclination was calculated using a slightly generalized surface model, and the values were divided into 7 classes: $0-1.9^{\circ} ; 2-5.9^{\circ} ; 6-11.9^{\circ} ; 12-19.9^{\circ} ; 20-31.9^{\circ} ; 32-54.9^{\circ}$; and more than $55^{\circ}$, with dolines occurring only in the first five. Descriptive statistics were used to analyse the occurrence and morphometry was analysed within each of the classes.

A total of 2805 dolines were analysed in this study. The collective average density is 175.1 dolines $/ \mathrm{km}^{2}$. The highest density was found in areas with slopes between 0 and $1.9^{\circ}\left(323.3\right.$ dolines $\left./ \mathrm{km}^{2}\right)$ and the lowest in areas with slopes between 20 and $31.9^{\circ}$ (12.6 dolines $/ \mathrm{km}^{2}$ ). Exceptionally high densities were also documented in areas with slope between 2 and $5.9^{\circ}$, confirming the results of Kranjec (1981), Ravbar and Zorn (2003) and Frelih (2014), who found that doline density was the highest at slopes up to $5^{\circ}$. The correlation coefficient between slope inclination and doline density is -0.9755 , which confirms the inverse proportionality between these two variables. Moreover, we found that dolines are not present on slopes with the inclination greater than $24^{\circ}$, which confirms that dolines occur on balanced slopes, where mechanical and chemical erosion balance each other or chemical erosion predominates, which enables the preservation of geomorphic forms (Frelih, 2014; Stepišnik, Kosec, 2011). The parameters chosen for morphometric analysis were the area, depth, axial length, circularity index and perimeter. The average doline has an area of $552.7 \mathrm{~m}^{2}$, is 6.5 $\mathrm{m}$ deep, its perimeter is $78.4 \mathrm{~m}$, the length of the shorter axis is $21.1 \mathrm{~m}$, the length of the longer axis is $27.5 \mathrm{~m}$, and the circularity index is 0.88 . On average, dolines on Hrušica are the largest, followed by dolines on Snežnik, and dolines on Slavnik are the smallest. We confirmed the finding of Frelih (2014) that doline density is the highest where dolines are the smallest. However, according to our research, the proportionality between density and doline dimensions is not inverse, as doline density is higher on Snežnik than on Hrušica. The area, perimeter and axis lengths of the dolines are very much inversely proportional to the slope gradient, which does not affect the relationship between the axes and thus the circularity index, which is $0.88-0.89$ on average. We also found that the higher slope of the doline is usually steeper and that there is no dominant orientation of the longer axis with respect to the direction of the slope. Therefore, we can refute the claim that dolines on slopes are asymmetric due to the slope itself and that they are elongated in the direction of the slope as well as that their higher slope is supposedly less steep than their lower slope (Ford, Williams, 2007; Jennings, 1971). We assume that geological structure has a greater influence on the orientation of the longer axis than the direction of the slope (Bahun, 1969; Čar, 1982; Frelih, 2014; Verbovšek, 2020). The depth of the studied slopes changes directly proportional to the slope inclination (correlation coefficient 0.9766 ), which could mean that deepening is more intense on slopes with higher inclination and widening on slopes with lower inclination. Nevertheless, we cannot assert this with certainty because the research did not analyse the shape of dolines in bedrock and did 
not include the analysis of geological structures. We also cannot refute Habičss (1981) claim that older dolines are usually deeper, as we have no information on the age of the studied dolines. As the most important result of the study, we can confirm that the density and morphological characteristics of dolines change depending on the slope of the area where they occur. They occur on balanced slopes, in the case of this study up to gradient slope of $24^{\circ}$. Their density decreases inversely proportional to the increase in slope. The average area, perimeter and axis lengths decrease with increasing slope, while on the other hand their depth increases. The circularity index remains approximately the same regardless of the slope. We also found that the orientation of the longer axes does not depend on the direction of the slope, which means that it is more influenced by the geological structure.

(Translated by the author) 